\title{
Non-trivial solution chemistry between amido-pyridylcalix[4]arenes and some metal salts $\dagger$
}

\author{
John J. Colleran, ${ }^{a}$ Bernadette S. Creaven, ${ }^{b}$ Denis F. Donlon ${ }^{a, b}$ and John McGinley ${ }^{\star a}$ \\ Received 6th August 2010, Accepted 1st September 2010 \\ DOI: 10.1039/c0dt00976h
}

\begin{abstract}
Mercury ion complexation reactions were carried out between 3 and various mercury(II) salts. ${ }^{1} \mathrm{H}$ NMR studies showed that the role of solvent, the anion chosen and the initial reaction conditions were critical and that the formation of a "simple" mercury(II) complex was non-trivial. The mercury(II) ion can cause either (i) the formation of an ion-pair system, which have a characteristic doubling of all signals in the ${ }^{1} \mathrm{H}$ NMR spectrum, (ii) a cleavage reaction to occur resulting in the reformation of the calix[4]arene diester compound 2, but only when the reaction is heated and (iii) "simple" mercury binding to the pyridine rings when the binding studies are carried out using NMR titration techniques. The electrochemistry results, on the same systems, show that the initial reaction involves the removal of the phenoxide protons followed by the resulting catalysis of the mercury species. This proton removal is not observed in the NMR spectra of any of the mercury reactions. It was also found that $\mathbf{3}$ could bind silver and zinc salts and was not selective for mercury(II) as was previously described.
\end{abstract}

\section{Introduction}

The last decade has witnessed a surge of interest in the discovery of building blocks capable of forming specific molecular arrays under certain chemical conditions. ${ }^{1-4}$ Calix[4]arenes are currently among the most versatile and useful building blocks in supramolecular chemistry, ${ }^{5-14}$ as they are intriguing platforms for constructing selective receptors because of their preorganised basket structure assembled from their four phenol rings. They are widely used for the creation of selective metal cation extractants (including radionuclides), catalysts and sensor materials and they have been functionalised by various receptor groups, which can selectively bind cations, anions, and neutral molecules. Calix $[n]$ arenes $(n=4$ or 6) have been used as three-dimensional receptors with multiple urea, thiourea or amido arms on either the wide or narrow rim to bind ion pairs in low polarity solvents. ${ }^{15}$ Calix[4]arene pyridyl ligands have been reported previously with methanol solvent molecules contained within the lattice being hydrogen bonded to the pyridyl nitrogen atoms ${ }^{16}$ and with the methanol molecule enclathrated within the calix[4] arene cone-shaped cavity. ${ }^{17}$ As part of our continuing research, we have previously reported upper and lower rim functionalised calix[4]arenes, capable of binding transition metal salts. ${ }^{18-21}$ In extending this theme, we targeted the design of "pre-ligands", capable of having two or more donor atoms present, with a view to attaching these to the lower rim of the calix[4]arene and have reported the copper(II) complexes of two such ligands. ${ }^{22,23}$ A recent paper by Rao and co-workers ${ }^{24}$ on the formation of calix[4]arene scaffolds containing pyridine ligands

${ }^{a}$ Chemistry Department, National University of Ireland Maynooth, Maynooth, Co.Kildare, Ireland. E-mail:john.mcginley@nuim.ie; Fax: +353 1708 3815; Tel: +35317084615

${ }^{b}$ Department of Science, Institute of Technology Tallaght Dublin, Dublin 24, Ireland. E-mail: bernie.creaven@it-tallaght.ie; Fax: +3531404 2700; Tel: +35314042889

$\dagger$ Electronic supplementary information (ESI) available: Tables containing ${ }^{1}$ H NMR complexation data. See DOI: 10.1039/c0dt00976h on the lower rim, attached via an amide bond, was interesting as it suggested that the calix[4]arene derivative selectively complexed mercury ions. This is contrary to what we have observed and in this paper we report the reactions of the same calix[4]arene derivative with mercury, silver and zinc salts and the subsequent ion pair interactions.

\section{Results and discussion}

\section{Ligand synthesis and characterisation}

The calix[4]arene diester compound $\mathbf{2}^{19,25}$ was heated to reflux for $120 \mathrm{~h}$ with 2-(aminomethyl)pyridine in a methanol-toluene solvent mixture (Scheme 1), similar to that previously described. ${ }^{18,26}$ The reaction yielded the amide $\mathbf{3}$ as a white solid in good yield. Compound $\mathbf{3}$ has recently been reported by Rao using a different preparative route, ${ }^{24}$ and the ${ }^{1} \mathrm{H}$ NMR data are comparable in both cases. The ${ }^{1} \mathrm{H}$ NMR spectrum of 3 consists of two signals being observed for both the aromatic protons of the calix[4]arene and the tert-butyl groups, indicative of 1,3-disubstitution at the lower rim, as well as a singlet for the hydroxyl groups on the lower rim. Cone conformation of the derivatised calix[4]arene was confirmed in all cases by the presence of two sharp doublets at approximately 4.4 and $3.3 \mathrm{ppm}$. The pendant arms attached to the calix[4]arenes gave the expected ${ }^{1} \mathrm{H}$ NMR data. Four signals in the aromatic region are observed for the substituted pyridine ring.

Crystals of 3 suitable for X-ray crystallographic study were obtained from methanol, and the structure was confirmed to be identical to that published by Rao and co-workers. ${ }^{24}$

\section{Complexation reactions}

The calixarene derivative 3 was reacted with mercury(II), silver(I) and zinc(II) salts $\left(\mathrm{HgX}_{2}, \mathrm{AgX}, \mathrm{ZnX}_{2} ; \mathrm{X}=\right.$ perchlorate, thiocyanate and chloride) in a $1: 1$ metal to ligand ratio in ethanol at room temperature for $2 \mathrm{~h}$. Precipitation did not occur in any case, 


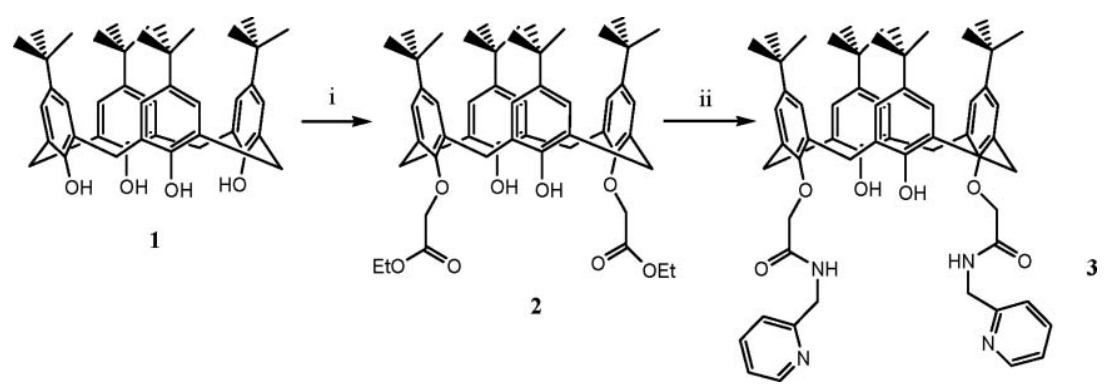

Scheme 1 Reagents and conditions: i) ethyl bromoacetate, $\mathrm{K}_{2} \mathrm{CO}_{3}, \mathrm{MeCN}, \Delta, 18 \mathrm{~h}$; ii) 2-(aminomethyl)pyridine, $\mathrm{MeOH}$, toluene, $120 \mathrm{~h}$.

and following the removal of the solvent, the remaining white solids were characterised by both NMR and IR spectroscopies (see Experimental section). When samples were left for several days, it was only on evaporation of the entire solution did a solid appear.

Electrospray (ESI) mass spectrometry of $\mathbf{3}$ and it's metal complexes were obtained in either $\mathrm{MeCN}$ or $\mathrm{CHCl}_{3}$ as solvent. In all cases, only the spectrum of $\mathbf{3}$ was obtained, with either sodium or potassium ions attached (see Experimental section). No evidence of a mercury, silver or zinc complex could be obtained.

\section{NMR studies}

The ${ }^{1} \mathrm{H}$ NMR spectrum of the $\mathrm{Hg}\left(\mathrm{ClO}_{4}\right)_{2}$ complex of calixarene 3 was run in both $\mathrm{d}_{6}-\mathrm{DMSO}$ and $\mathrm{CD}_{3} \mathrm{CN}$. Both the $\mathrm{d}_{6}$-DMSO and the $\mathrm{CD}_{3} \mathrm{CN}$ spectra showed the presence of a single set of signals and, based on the shifts of the signals in comparison to the starting calixarene derivative $\mathbf{3}$, the species present was identified as the mercury(II) complex (see Fig. 1). In both solvents, there are significant shifts in the signals related to the pyridyl protons, indicating binding of the mercury(II) cation at this position. Furthermore, there are also shifts in the signals for both the amide protons and the hydroxyl protons on the lower rim of the calixarene, indicative of the binding of the mercury(II) cation to the pyridine rings, causing a change in the electron density at the amide resulting in a weakening of the hydrogen bonding between the amide hydrogen and the phenolic oxygen. We also obtained the ${ }^{1} \mathrm{H}$ NMR spectrum in $\mathrm{CDCl}_{3}$. While, all the signals present were well-defined, the spectrum, shown in part in Fig. 2, was neither that of the calixarene derivative 3 on its own, nor did it show simple mercury complexation (as observed in Fig. 1), as there are now double the number of signals that should be present, for the latter explanation. This means that either there are either two different species present in solution or that the complexation of the mercury ion is giving rise to a single highly asymmetric species in solution, as indicated below.

Removal of the solvent under reduced pressure and redissolving the sample in $\mathrm{CD}_{3} \mathrm{CN}$ or $\mathrm{d}_{6}$-DMSO resulted in spectra similar to that shown in Fig. 1, with the obvious difference of solvent peaks. When a sample of the mercury(II) perchlorate complex was run in $\mathrm{CD}_{2} \mathrm{Cl}_{2}$, the resulting ${ }^{1} \mathrm{H}$ NMR spectrum also contained a doubling of all signals, similar to that shown in Fig. 2. A plausible suggestion, based on these spectral results, is that the doubling of the spectral signals in $\mathrm{CDCl}_{3}$, and also in $\mathrm{CD}_{2} \mathrm{Cl}_{2}$, is due to the lack of solvation of the perchlorate anion, something which is happening in the donor solvents. We therefore believe that the mercury(II) cation is binding to the pyridyl arms of the functionalised calix[4]arene, thereby separating itself from the perchlorate anion. When this happens in $\mathrm{d}_{6}-\mathrm{DMSO}$ or $\mathrm{CD}_{3} \mathrm{CN}$, then the anion is solvated by donor solvent molecules, whereas

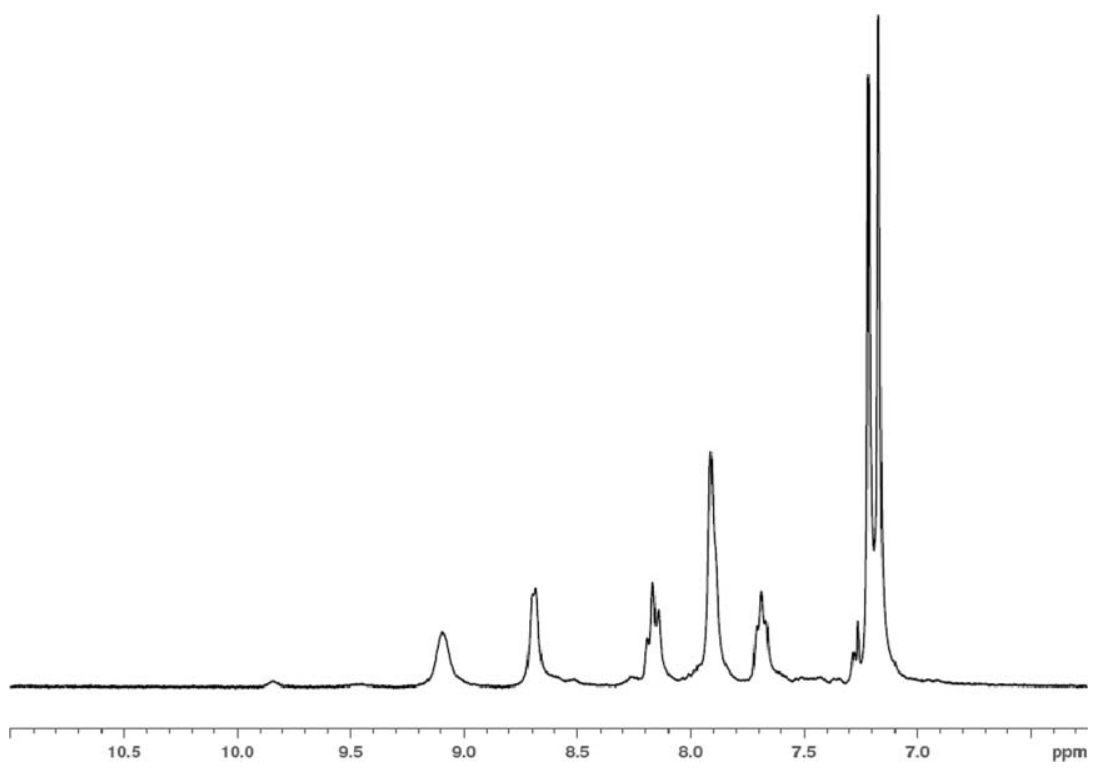

Fig. $1300 \mathrm{MHz}^{1} \mathrm{H}$ NMR spectrum of mercury(II) perchlorate complex in $\mathrm{CD}_{3} \mathrm{CN}$ from $6.25-11 \mathrm{ppm}$. 


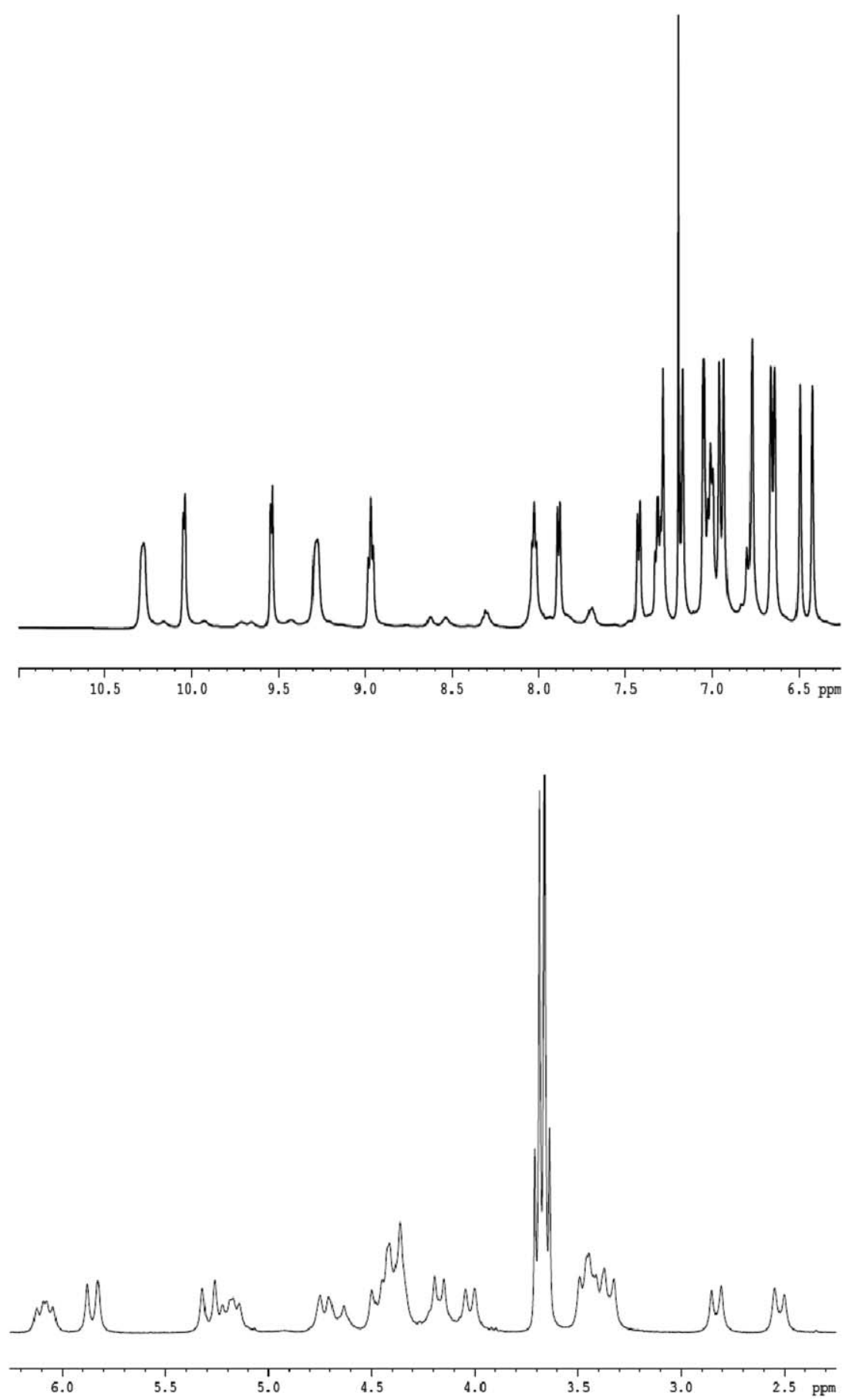

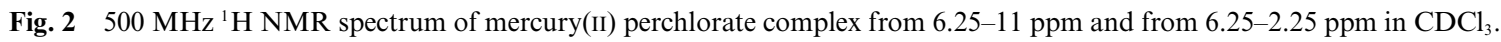

when the solvent is $\mathrm{CDCl}_{3}$ or $\mathrm{CD}_{2} \mathrm{Cl}_{2}$, no solvation occurs due to the poor donating ability of these solvents and the resulting close ion-pairing induces a high degree of asymmetry in the complex.

Closer inspection of the NMR spectra in ion-pairing solvents reveals the following: for the methylene protons, there are now four sets of doublets in the 6.25-2.25 ppm region, as shown in Fig. 2 , which would indicate that each proton on the methylene bridge is in a unique environment. Assignment of each signal in the ${ }^{1} \mathrm{H}$ NMR spectrum, obtained in $\mathrm{CDCl}_{3}$, has found that every proton within coupling distance is now involved in a coupling process. For example, the methylene group attached to the phenoxide oxygen and the carbonyl carbon at the upper end of the pendant arm is a singlet in the ${ }^{1} \mathrm{H}$ NMR spectrum of 3 at $4.56 \mathrm{ppm}$ but now both protons couple to each other to give a pair of doublets at $4.17,3.35,2.83$ and at $2.53 \mathrm{ppm}$. It is difficult to see how the mercury(II) ion induces asymmetry into the calix[4]arene molecule but the complexity of the NMR spectrum confirms this asymmetry. Several samples of the perchlorate complex, in both $\mathrm{CHCl}_{3}$ and $\mathrm{CDCl}_{3}$ solution, were left aside in an effort to 


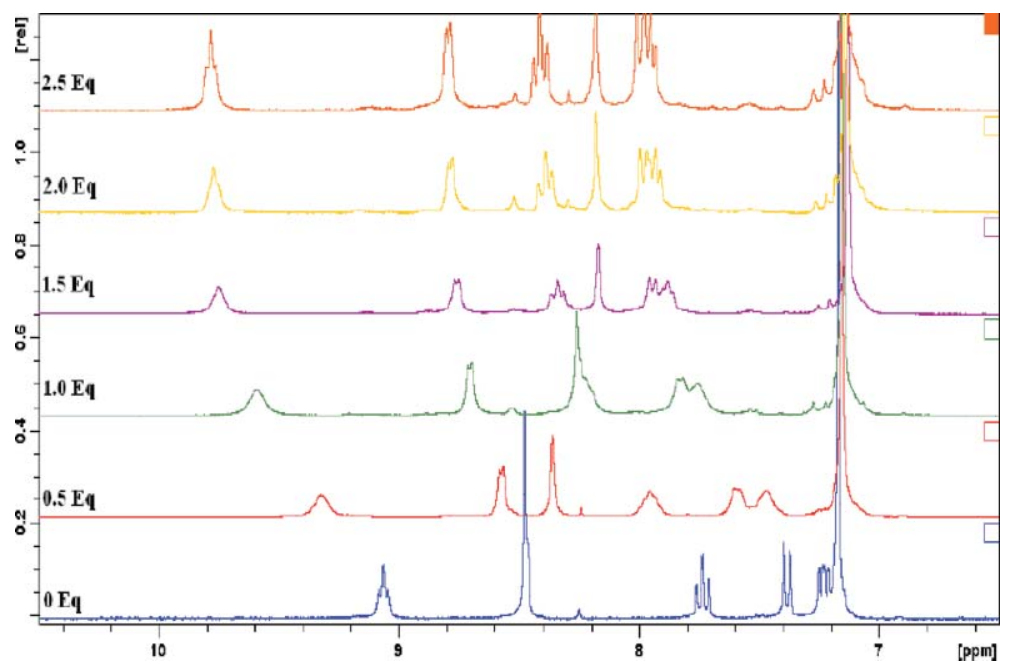

Fig. $3300 \mathrm{MHz}{ }^{1} \mathrm{H}$ NMR spectra measured at $25^{\circ} \mathrm{C}$ during the titration of $\mathbf{3}$ with mercury(II) perchlorate in $\mathrm{d}_{6}$-DMSO.

obtain suitable crystals for an X-ray structural determination. Where crystals were obtained, they analysed as the starting calix[4]arene 3 .

Titration studies between 3 and mercury(II) perchlorate in various deuterated solvents, particularly in $\mathrm{CDCl}_{3}$, might be informative about the number of species present in solution. So, these studies were undertaken using various concentrations of metal salt to one equivalent of $\mathbf{3}$. The titration study between $\mathbf{3}$ and mercury(II) perchlorate in $\mathrm{CDCl}_{3}$ could not be carried out because of the poor solubility of mercury(II) perchlorate in the solvent, even at the low concentrations required for the titration. The titration studies between mercury(II) perchlorate and 3 in $\mathrm{CD}_{3} \mathrm{CN}$ and $\mathrm{d}_{6}$ DMSO at variable temperatures and concentrations were carried out and showed, in all cases, that metal binding was observed. In either solvent, the ${ }^{1} \mathrm{H}$ NMR spectra showed no change in the cone conformation. It was observed that the chemical shift separation of the proton signals of the methylene bridge in $\mathbf{3}$ decreased, suggesting that the ligand adopts a more symmetrical cone conformation upon complexation. However, considerable shifts in the amide, hydroxyl and pyridyl proton signals were observed in the spectra. Fig. 3 shows the spectra obtained when 1 equivalent of 3 is titrated with various concentrations of $\mathrm{Hg}\left(\mathrm{ClO}_{4}\right)_{2}$ up to 2.5 equivalents of metal salt at $25{ }^{\circ} \mathrm{C}$. Both the pyridyl and amide protons showed the largest downfield shift, indicating that the $\mathrm{Hg}$ (II) cation mainly interacts with both the pyridyl and amide parts of the calix[4]arene derivative. Such downfield shifts have been previously reported for other mercury(II)-bound complexes. ${ }^{24,27-29}$
As titration studies in $\mathrm{CDCl}_{3}$ and $\mathrm{CD}_{2} \mathrm{Cl}_{2}$ were not successful it was decide to try to isolate the mercury(II) complexes under different conditions to see if a number of species existed in solution. Varying the time of reaction, temperature or solvent did not result in complexes of different conformation or symmetries but did give rise to an unusual outcome. The initial reaction between mercury(II) perchlorate and $\mathbf{3}$ was also repeated in ethanol but this time at the reflux temperature of the solvent for $2 \mathrm{~h}$, instead of being at room temperature for $2 \mathrm{~h}$. On cooling, a white solid precipitated from the reaction mixture. Analysis of the ${ }^{1} \mathrm{H}$ NMR spectrum, using $\mathrm{CDCl}_{3}$ as solvent, showed that the calix[4]arene derivative has lost both pendant pyridyl arms and that the cleavage has occurred between the amide carbonyl and nitrogen atoms. The calix[4]arene derivative that is obtained as a result of these cleavage reactions is the calix[4]arene diester $\mathbf{2}$. It is not clear why the cleavage should occur under such mild conditions as heating to reflux temperature in ethanol. One possible mechanism which would allow the cleavage reactions to occur is outlined in Scheme 2. The ethyl ester which is obtained results from the choice of ethanol as solvent.

Based on our room temperature reactions and binding studies, we believe that the reaction between $\mathbf{3}$ and the mercury(II) perchlorate salt results initially in the formation of the cationic mercury(II)-calix[4]arene complex with perchlorate anions present in solution. For the purposes of clarity, the mercury ion is only bound to one pyridine ring in the Scheme. The mercury ion is also involved in an interaction with the amide carbonyl oxygen atom. As a result of this interaction, an ethanol molecule can

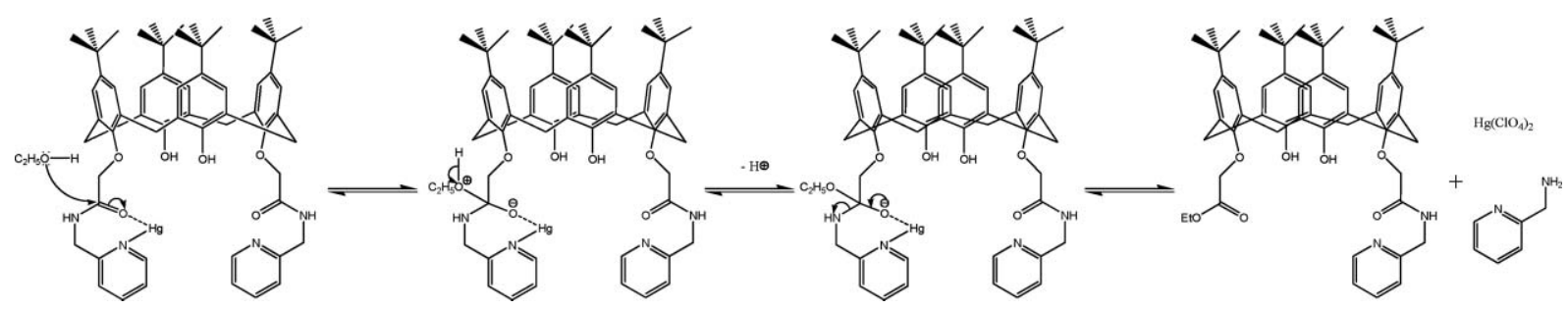

Scheme 2 Possible mechanism for cleavage reaction. The mercury ion is not shown as being charged in the Scheme. 
attack the carbonyl carbon atom, resulting in the bonding of the alcohol to the carbonyl carbon atom. Loss of a proton followed by a rearrangement of the electrons gives the amide carbonyl group back, which is still bonded to the mercury ion, and also cleaves the $\mathrm{C}-\mathrm{N}$ amide bond to give the ester and, on protonation, the 2-aminomethylpyridine compound. The ethanol molecule is only shown attacking one pendant arm of the calixarene derivative in Scheme 2, but attack does occur at both amide carbonyls. If this mechanism is feasible, then replacing ethanol by methanol as solvent should result in the formation of the methyl ester calix[4]arene derivative. This reaction was carried out using methanol as solvent and heating the mixture to the reflux temperature of methanol for two hours. The resulting white solid was analysed by ${ }^{1} \mathrm{H}$ NMR spectroscopy and revealed that the methyl ester derivative was indeed formed, which suggested that our proposed mechanism was feasible. Furthermore, when we repeated the reaction in either ethanol or methanol but this time reduced the reaction time to $1 \mathrm{~h}$, the solid obtained had lost one pendant arm only.

The reaction was also repeated using perchloric acid instead of mercury(II) perchlorate in order to see was the presence of the mercury(II) ion essential for the cleavage reaction to occur. The reaction was carried out for two hours at both room temperature and at the reflux temperature of ethanol. Once the excess solvent had been removed under vacuum, the residue in both cases was analysed using ${ }^{1} \mathrm{H}$ NMR spectroscopy using $\mathrm{CDCl}_{3}$ as solvent. In both cases, significant shifts in the pyridyl signals were observed, which suggested that the corresponding pyridinium cations were being formed. The differences in the chemical shift values on going from the pyridine derivative 3 to the pyridinium cation were similar to those observed and reported by Beer and co-workers. ${ }^{30}$ Therefore, the presence of the mercury(II) ion is essential for the cleavage reaction to occur.

\section{Studies with other metal ions}

Although Rao and co-workers ${ }^{24}$ had reported that $\mathbf{3}$ was selective for mercury(II), we were interested in studying the complexation reactions with other metal ions to see if the unusual behaviour displayed by the mercury(II) complexes of $\mathbf{3}$ was evident in other complexes. The reaction of $\mathbf{3}$ with either silver(I) perchlorate or zinc(II) perchlorate was carried out for two hours at both room temperature and at the reflux temperature of ethanol. The resulting white solids, obtained from each reaction after removal of solvent in vacuo, were analysed using ${ }^{1} \mathrm{H}$ NMR spectroscopy using $\mathrm{CDCl}_{3}$ as solvent. In all cases, binding of either the silver(I) ion or the zinc(II) ion to the pyridine ring was observed, but without the doubling of peaks indicative of the presence of an ion-pair either, as shown in Fig. 1 for the mercury(II) case, or the cleavage reaction occurring, as observed when the reaction with mercury(II) perchlorate was carried out at high temperature for two hours. ${ }^{1} \mathrm{H}$ NMR titration studies were subsequently undertaken between 3 and silver(I) perchlorate in $\mathrm{d}_{6}$-DMSO respectively. Binding of the silver(I) ion to the pyridine ring was observed, which is similar to the binding pattern observed when using mercury(II) perchlorate, suggesting that the mercury(II) and silver(I) cations interact with the calix[4]arene derivative in the same manner.

\section{Fluorescence studies}

The binding of zinc(II) perchlorate and silver(I) perchlorate to 3 contradicts the findings of Rao and co-workers who published their work on the binding of metal(II) salts to various amide linked derivatives of calix[4]arene. ${ }^{24}$ In the course of their work, they studied the interaction of eleven different divalent metal ions, including both $\mathrm{Hg}$ (II) and $\mathrm{Zn}$ (II), with 3 in 50\% aqueous acetonitrile by fluorescent spectroscopy. They reported that only in the case of the $\mathrm{Hg}$ (II) cation were any significant changes in fluorescence observed. We decided to use fluorescence spectroscopy to see if we could obtain similar results to Rao and co-workers, as there may be sensitivity issues between ${ }^{1} \mathrm{H}$ NMR spectroscopy and fluorescence spectroscopy. We dissolved 3 in $50 \%$ aqueous acetonitrile to obtain the same concentration $(10 \mu$ molar $)$ as used by Rao and coworkers and then ran it's fluorescence spectrum. We also made up a $10 \mu$ molar 1:1 solution of $\mathbf{3}$ and $\mathrm{Hg}\left(\mathrm{ClO}_{4}\right)_{2}$ and also obtained it's spectrum. Both spectra showed weak fluorescence but it was not possible to observe a difference in fluorescence between the two spectra, as observed by Rao and co-workers. ${ }^{24}$ We therefore decided to repeat the fluorescence studies using a tenfold increase in concentration. Using the $100 \mu$ molar solution of $\mathbf{3}$, we observed the expected increase in absorption due to the concentration effect. The spectrum of the metal complex showed an obvious decrease in fluorescence (see Fig. 4), as expected when using a mercury(II) salt. When a second equivalent of $\mathrm{Hg}\left(\mathrm{ClO}_{4}\right)_{2}$ was added, the fluorescence showed a further decrease. This confirmed the observations of Rao, although it was at a higher concentration. We have also found a similar decrease in fluorescence when we carried out titration studies of $\mathbf{3}$ with zinc(II) perchlorate.

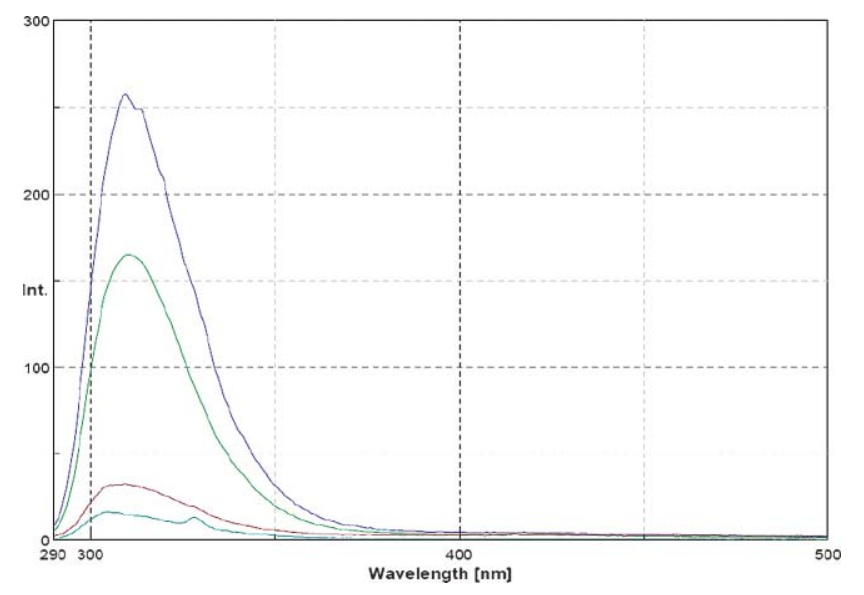

Fig. 4 Fluorescence titration spectra measured during the titration of 3 with mercury(II) perchlorate complex in $50 \%$ aqueous acetonitrile solution; dark blue line $=\mathbf{3}$, green line $=\mathbf{3}+\mathrm{Hg}\left(\mathrm{ClO}_{4}\right)_{2}(1: 1)$, red line $=\mathbf{3}+\mathrm{Hg}\left(\mathrm{ClO}_{4}\right)_{2}$ $(1: 2)$, pale blue line $=\mathbf{3}+\mathrm{Hg}\left(\mathrm{ClO}_{4}\right)_{2}(1: 5)$.

\section{Electrochemistry studies of mercury(II) and silver(I) complexes}

The electrochemical behaviour of $\mathbf{3}$, and metal binding to $\mathbf{3}$, was investigated in acetonitrile, chosen due to its inertness within a large potential window, ${ }^{31}$ with $0.1 \mathrm{M} \mathrm{TBAPF}_{6}$ as supporting electrolyte. Cyclic voltammetry (CV) was performed on a Solartron potentiostat Model 1285, while a PAR Model 636 was employed to perform RDE Voltammetry (RDV). The working 
Table 1 Summary of parameters obtained for the different analytes

\begin{tabular}{lll}
\hline Cyclic voltammetry & & \\
\hline Analyte $\left(1 \times 10^{-3} \mathrm{M}\right)$ & $E_{\mathrm{p}, \mathrm{ox}} / \mathrm{V}$ & Potential shift/V \\
\hline $\mathbf{3}$ & 1.490 & - \\
$\mathbf{3}-\mathrm{Hg}\left(\mathrm{ClO}_{4}\right)_{2}$ & 1.749 & +0.259 \\
$3-\mathrm{AgClO}_{4}$ & 1.620 & +0.130 \\
\hline
\end{tabular}

electrodes were platinum disks $\left(\mathrm{CV}, A=0.0314 \mathrm{~cm}^{2}\right.$; RDV, $A=$ $0.1257 \mathrm{~cm}^{2}$ ) and platinum wire counter electrodes. Solutions were deaerated by purging with $\mathrm{N}_{2}$ for 15 mins prior to experiments. All potentials are quoted versus a $\mathrm{Ag} / \mathrm{Ag}+$ reference electrode $\left(E_{1 / 2}=\right.$ $+0.075 \mathrm{~V}$ vs. $\mathrm{FeCp}_{2}$ ), which comprised of a silver wire sealed in glass, containing $0.01 \mathrm{M} \mathrm{AgNO}_{3}$ and $0.1 \mathrm{M} \mathrm{TBAPF}_{6}$ in $\mathrm{MeCN}$. Concentrations of $\mathbf{3}$, and all the metal salts were analysed in $1 \times$ $10^{-3} \mathrm{M}$ concentrations. The voltammograms were swept anodically (unless otherwise stated) in the potential window -1.0 to $+1.9 \mathrm{~V}$ at a scan rate of $100 \mathrm{mV} \mathrm{s}^{-1} . E_{\mathrm{p}}$ values and other derived parameters are summarised in Table 1.

\section{Electrochemistry of 3}

The hydroxyl groups on the calix[4]arene derivative are the prime candidates to infer $\mathbf{3}$ with electroactivity. Typical cyclic voltammograms for a $1 \times 10^{-3} \mathrm{M}$ solution of $\mathbf{3}$, shown in Fig. 5 (black trace), display a small oxidation peak at $+1.12 \mathrm{~V}$, a second very well defined oxidation peak at $c a .+1.49 \mathrm{~V}$, and a reduction peak at $c a$. $-0.48 \mathrm{~V}$. Both anodic peaks represent the oxidation and accompanying deprotonation of the hydroxyl group on $\mathbf{3}$, as has been observed in other studies performed on disubstituted calix[4]arenes. ${ }^{32}$ An ECE mechanism has been suggested for this process and a plot of $I_{\mathrm{p}} / v^{1 / 2}$ versus $v$ supports this. ${ }^{33} \mathrm{RDV}$ was used to analyse the main anodic peak. The slope of the plots of $E$ versus $\ln \left(\mathrm{i} / \mathrm{i}_{\mathrm{d}}-\mathrm{i}\right)$ can be used to determine the oxidation stoichiometry. A linear plot was observed with a slope of $92 \mathrm{mV} \mathrm{dec}{ }^{-1}$. This lies midway between the theoretical Nernstian predicted slope value for one and two electron processes. Our value would suggest that the first electron transfer is not solely rate determining, and that deprotonation of the hydroxide groups also contributes to the kinetic process. This observation would seem to support the

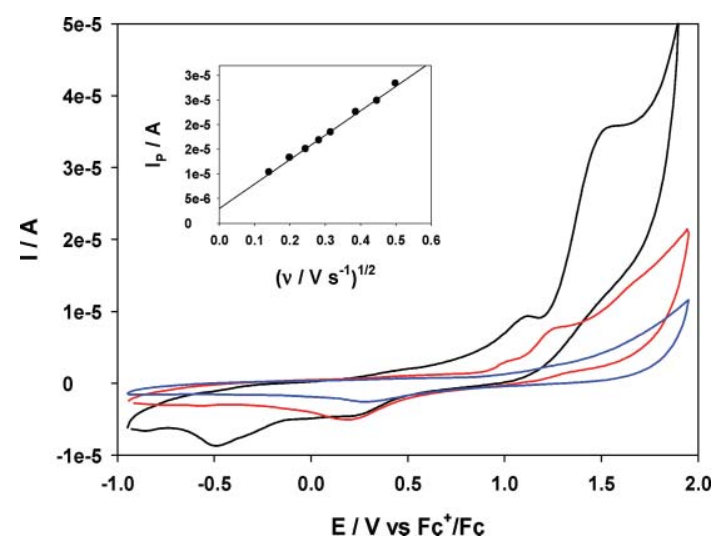

Fig. 5 Typical cyclic voltammograms detailing the redox behaviour $1 \times$ $10^{-3} \mathrm{M}$ of 3 (black trace), tetramer (red trace) and $\mathrm{MeCN}$ (blue trace) at a $\mathrm{Pt}$ working electrode. Supporting electrolyte was $0.1 \mathrm{M} \mathrm{TBAPF}_{6}$ and scan rate was $100 \mathrm{mV} \mathrm{s}^{-1}$. Inset: Randles-Sevcik plot. proposed ECE mechanism. Our values differ from those obtained for diamide-calix[4]arene, ${ }^{32 \mathrm{~b}}$ which differs from $\mathbf{3}$ only by the two non-phenolic pendants. This would indicate, unexpectedly, that the two pyridyl pendants impose a bearing on the oxidation process at the phenolic groups. The origin of the cathodic peak was determined by cycling 3 from +0.8 to $-1.0 \mathrm{~V}$, that is to potentials that did not oxidise 3 . The reduction peak at $-0.48 \mathrm{~V}$ was absent indicating that the reduction peak is an electrochemically generated daughter peak of the oxidation process (not shown). All voltammograms exhibit a reduction peak at $+0.35 \mathrm{~V}$, which has previously been reported as the reduction of protons at $\mathrm{Pt}^{34}{ }^{34} \mathrm{To}$ investigate whether the redox behaviour of $\mathbf{3}$ was indeed due to the hydroxyl groups, potential cycling of a $1 \times 10^{-3} \mathrm{M}$ solution of the parent tetramer (only hydroxyl groups present) was carried out (Fig. 6, red trace). Both the pre-peak and the larger oxidation peak are observed at around the same potentials. The slightly lower oxidation potentials and smaller oxidation peak currents are observed due to the poor solubility, and thus lower concentration, of the tetramer in $\mathrm{MeCN}$.

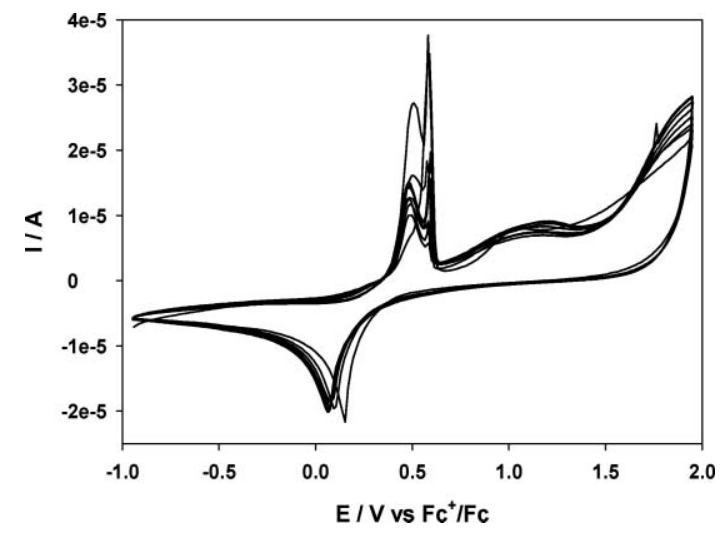

Fig. 6 Typical cyclic voltammograms detailing the redox behaviour of $\mathrm{Hg}\left(\mathrm{ClO}_{4}\right)_{2}\left(1 \times 10^{-3} \mathrm{M}\right)$ in $\mathrm{MeCN}$ at a Pt working electrode. Supporting electrolyte was $0.1 \mathrm{M} \mathrm{TBAPF}_{6}$ and scan rate was $100 \mathrm{mV} \mathrm{s}^{-1}$.

The daughter reduction peak was not evident in the voltammetric profile of the tetramer, which may indicate that the pyridyl pendant groups promote the generation of this species. The oxidation peak of compound $\mathbf{3}$ has a diffusion-like character and a scan rate analysis was performed to investigate. The resultant Randles-Sevcik plot, shown as inset in Fig. 5, was linear and had a slight non-zero intercept. The non-zero intercept was not unexpected due to the fact that only the second oxidation peak was considered in the analysis. This is typical of $\mathrm{R}-\mathrm{S}$ behaviour and thus the oxidation of $\mathbf{3}$ was deemed to be under diffusion control.

\section{Redox behaviour of $\mathrm{Hg}\left(\mathrm{ClO}_{4}\right)_{2}$ in $\mathrm{MeCN}$}

Mercury(II) is well known to undergo a reversible two electron reduction to form the insoluble mercury(0). This transition leads to the formation of thin films on electrode surfaces and is described by Reaction 1:

$$
\mathrm{Hg}(\mathrm{II})+2 \mathrm{e}^{-} \leftrightarrow \mathrm{Hg}^{0}
$$

The corresponding oxidation is evident in cyclic voltammograms as a sharp stripping peak which causes the mercury dissolution. We chose to study the electrochemical properties of 
$\mathrm{Hg}\left(\mathrm{ClO}_{4}\right)_{2}$ and its interaction with 3 because $\mathrm{Hg}\left(\mathrm{ClO}_{4}\right)_{2}$ dissociates readily into $\mathrm{Hg}^{2+}$ cations and $\mathrm{ClO}_{4}{ }^{-}$anions in $\mathrm{MeCN}$. Therefore the solution should be rich in $\mathrm{Hg}^{2+}$ ions, as is evident in the first cyclic voltammetric cycle outlined in Fig. 6 (dotted trace). We observe a sharp oxidation peak at $+0.59 \mathrm{~V}$, corresponding to the stripping of $\mathrm{Hg}^{0}$ from the Pt surface. The coupled reduction peak, $\mathrm{Hg}^{2+}$ to $\mathrm{Hg}^{0}$, lies at $+0.15 \mathrm{~V}$ but progressive scans document a shift to more cathodic values, which settle out at $0.07 \mathrm{~V}$. The second peak associated with the stripping process, ${ }^{35,36}$ similar in height to the original peak, appears in cycle 2 at $+0.51 \mathrm{~V}$. Both stripping peaks decrease in magnitude with cycle number, while the reduction of $\mathrm{Hg}^{2+}$ to the insoluble $\mathrm{Hg}^{0}$ remains relatively stable.

\section{Electrochemistry of $\mathrm{Hg}\left(\mathrm{ClO}_{4}\right)_{2}$ - 3 complex}

Due to the ready dissociation of $\mathrm{Hg}\left(\mathrm{ClO}_{4}\right)_{2}$ in $\mathrm{MeCN}$, mercury will exist as $\mathrm{Hg}^{2+}$ ions, which are known to favour interaction with soft Lewis bases. The nitrogen on the pendant pyridine should be an ideal binding site candidate, as proposed by NMR analysis. In the presence of $\mathrm{Hg}\left(\mathrm{ClO}_{4}\right)_{2}$, we observe a relatively large anodic shift in the oxidation potential of $\mathbf{3}$, which is indicative of mercury-ligand binding (Fig. 7). The $E_{\mathrm{p}, 0 x}$ for 3 is present at $+1.46 \mathrm{~V}$ on cycle 1 , but shifts to $+1.75 \mathrm{~V}$ thereafter. The same peaks that appear in the parent $\mathrm{Hg}\left(\mathrm{ClO}_{4}\right)_{2}$ and ligand analyte solutions are again evident in this solution mixture. But after cycle 1, the familiar $\mathrm{Hg}^{0}$ stripping peak at $c a .+0.46 \mathrm{~V}$, indicative of mercury film formation, is no longer evident, which further supports a mercuryligand binding process. The peak at $+0.07 \mathrm{~V}$, however, actually increases in magnitude. Another interesting feature is the increase in peak intensity at $c a .+1.17 \mathrm{~V}$ with cycle number. One possibility that could account for this observation is that the electrochemical process, observed as the pre-peak, now becomes more pronounced and facile in the presence of $\mathrm{Hg}\left(\mathrm{ClO}_{4}\right)_{2}$. But since we observe a general increase in $\mathrm{Hg}^{2+}$ reduction, $\mathrm{Hg}^{0}$ is being oxidised, so we tentatively assign the peak at $+1.17 \mathrm{~V}$ to the combined oxidation processes of both mercury $\left(\mathrm{Hg}^{0}\right.$ to $\left.\mathrm{Hg}^{2+}\right)$ and ligand species. So, in conclusion, the presence of $\mathrm{Hg}\left(\mathrm{ClO}_{4}\right)_{2}$ actually impedes the oxidation of 3, possibly at the phenoxide sites, and may result because of a binding process. These observations imply that if binding occurs at the pyridyl pendant nitrogen, re-oxidation of metallic mercury may be hindered. Binding of $\mathrm{Hg}^{2+}$ to both pyridyl pendants may infer rigidity onto the mercury-calixarene complex and free rotation of the pendant arms is no longer facile. Loss

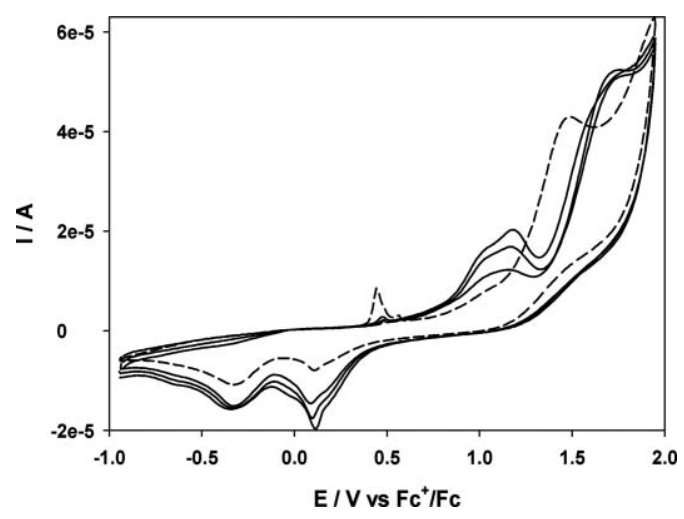

Fig. 7 The effect of $\mathrm{Hg}\left(\mathrm{ClO}_{4}\right)_{2}$ on the oxidation of 3 in $\mathrm{MeCN}$ and 0.1 $\mathrm{M} \mathrm{TBAPF}_{6}$. The scan rate employed was $100 \mathrm{mV} \mathrm{s}^{-1}$. of electrons and protons from the hydroxide moieties, at the $\mathrm{Pt}$ electrode surface, then becomes kinetically more sluggish.

Additional energy ( $290 \mathrm{mV}$ - anodic shift) is then required to oxidise the newly formed complex. Bound mercury ions have not affected diffusion of this complex to the electrode surface enough to observe a decline of the oxidation peak currents of 3 .

\section{Other perchlorate salts}

The effect of $\mathrm{AgClO}_{4}$ on the oxidation of $\mathbf{3}$ was also investigated and little bearing on the electrochemistry of $\mathbf{3}$ was observed. Unlike with $\mathrm{Hg}\left(\mathrm{ClO}_{4}\right)_{2}$, in the case of $\mathrm{AgClO}_{4}$, a $\mathrm{Ag}(0)-\mathrm{Ag}(\mathrm{I})$ stripping peak was present in all cyclic voltammetric potential sweeps (Cycle 1, black trace \& Cycle 10, blue trace, Fig. 8). The electrogenerated daughter peak appears after the first cycle and is observed in the blue and red traces. In the presence of $\mathrm{AgClO}_{4}$, the oxidation potential of 3 is shifted anodically by $\sim 130 \mathrm{mV}$, again indicative of a binding process. However, the magnitude of the $\mathrm{Ag}^{0}$ stripping peak remained constant over successive potential cycles in the presence of 3 . This would indicate that if the binding of $\mathrm{Ag}^{+}$occurs, it is reversible i.e. an equilibrium process, and the generation of $\mathrm{Ag}^{0}$ is not kinetically affected by complexation. We observed an opposite effect with $\mathrm{Hg}\left(\mathrm{ClO}_{4}\right)_{2}$ where a lower concentration of $\mathrm{Hg}^{2+}$ was free in solution to form the deposited $\mathrm{Hg}^{0}$ species upon reduction. An equilibrium binding process may account for these observations. The results presented here indicate that although metallic ions do interact with 3 when highly dissociated in $\mathrm{MeCN}$, only mercuric species exhibit a dramatic electrochemical effect on the oxidation of 3 . The rigidity inferred on the complex through binding should vary for the $\mathrm{Hg}^{2+}$ and $\mathrm{Ag}^{+}$ions. $\mathrm{Hg}$ is over twice the mass of Ag which may affect the magnitude of interaction strength between the different metal ions and the pyridyl pendants. Varying degrees of complex rigidity, inferred through the different species of metal binding, should then be reflected in the different potentials required to oxidise 3 .

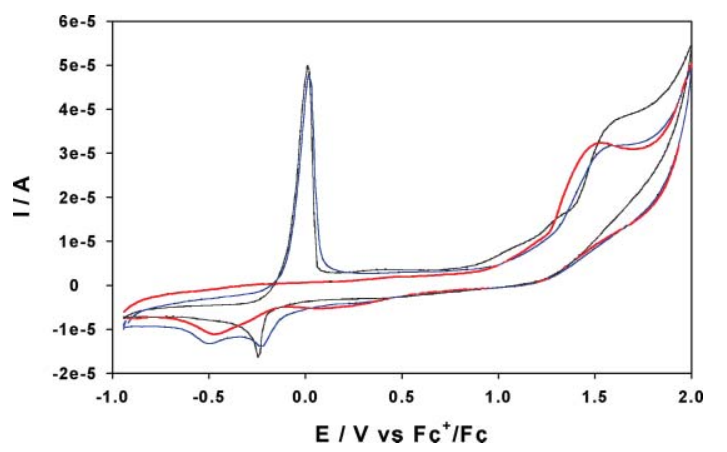

Fig. 8 Cyclic voltammograms describing the electrochemical behaviour of $1: 1$ solution mixtures of $\mathrm{AgClO}_{4}-\mathbf{3}$, cycle 1 (solid black trace) and $\mathrm{AgClO}_{4}-3$, cycle 10 (solid blue trace). The solid red trace is $1 \times 10^{-3} \mathrm{M} 3$ only. All data recorded in $0.1 \mathrm{M} \mathrm{TBAPF}_{6}$ in $\mathrm{MeCN}$ at a scan rate of 100 $\mathrm{mV} \mathrm{s}^{-1}$.

\section{Experimental}

${ }^{1} \mathrm{H}$ and ${ }^{13} \mathrm{C}$ NMR ( $\delta$ ppm; $J \mathrm{~Hz}$ ) spectra were recorded on either a JEOL JNM-LA300 FT-NMR spectrometer or a Bruker Bruker Avance III $500 \mathrm{MHz}$ spectrometer using saturated $\mathrm{CDCl}_{3}$ solutions with $\mathrm{Me}_{4} \mathrm{Si}$ reference, unless indicated otherwise, with 
resolutions of $0.18 \mathrm{~Hz}$ and $0.01 \mathrm{ppm}$ for the $300 \mathrm{MHz}$ machine and $0.005 \mathrm{~Hz}$ for the $500 \mathrm{MHz}$ machine, respectively. Infrared spectra $\left(\mathrm{cm}^{-1}\right)$ were recorded as $\mathrm{KBr}$ discs or liquid films between $\mathrm{KBr}$ plates using a Perkin Elmer System 2000 FTIR spectrometer. Melting point analysis was carried out using a Stewart Scientific SMP 1 melting point apparatus and are uncorrected. Microanalysis was carried out at the Microanalytical Laboratory of either University College, Dublin, the National University of Ireland Cork or the National University of Ireland Maynooth. Electrospray (ESI) mass spectra were collected on an Agilent Technologies 6410 Time of Flight LC/MS. Complexes were dissolved in acetonitrile-water $(1: 1)$ solutions containing $0.1 \%$ formic acid, unless otherwise stated. The interpretation of mass spectra was made with the help of the program "Agilent Masshunter Workstation Software". Standard Schlenk techniques were used throughout. Starting materials were commercially obtained and used without further purification. Caution! Although not encountered in our experiments, perchlorate salts of metal ions are potentially explosive and should be manipulated with care and used only in small quantities. The synthesis of compound $\mathbf{2}$ has been described in the literature previously. ${ }^{19,25}$

\section{Synthesis of 3}

A solution of $2(0.5 \mathrm{~g}, 0.6 \mathrm{mmol})$ and 2-aminomethylpyridine $(0.58 \mathrm{~g}, 2.4 \mathrm{mmol})$ in a mixture of methanol $(15 \mathrm{ml})$ and toluene $(15 \mathrm{ml})$ were allowed to stir at reflux temperature for $120 \mathrm{~h}$. After completion, the reaction solution was concentrated under reduced pressure. The resulting solid residue was crystallised from methanol, filtered and oven dried to yield the title compound. NMR data for 3: $\delta_{\mathrm{H}}\left(300 \mathrm{MHz} ; \mathrm{CDCl}_{3} ; \mathrm{Me}_{4} \mathrm{Si}\right) 0.99(18 \mathrm{H}, \mathrm{s}, t-\mathrm{Bu})$, $1.28(18 \mathrm{H}, \mathrm{s}, t-\mathrm{Bu}), 3.35\left(4 \mathrm{H}, \mathrm{d}, J=13.5 \mathrm{~Hz}, \mathrm{ArCH}_{2} \mathrm{Ar}\right), 3.65$ $(3 \mathrm{H}, \mathrm{s}, \mathrm{MeOH}), 4.25\left(4 \mathrm{H}, \mathrm{d}, J=13.5 \mathrm{~Hz}, \mathrm{ArCH}_{2} \mathrm{Ar}\right), 4.56(4 \mathrm{H}, \mathrm{s}$, $\left.\mathrm{OCH}_{2} \mathrm{CO}\right), 4.78\left(4 \mathrm{H}, \mathrm{d}, J=6 \mathrm{~Hz}, \mathrm{NHCH}_{2}\right), 6.85(4 \mathrm{H}, \mathrm{s}, \mathrm{Ar}-\mathrm{H})$, $7.06(4 \mathrm{H}, \mathrm{s}, \mathrm{Ar}-H), 7.15(2 \mathrm{H}, \mathrm{m}, \mathrm{py}-H), 7.43(2 \mathrm{H}, \mathrm{s}$, calix- $O H)$, $7.82(2 \mathrm{H}$, br t, py- $H), 8.42(2 \mathrm{H}$, br d, py- $H), 8.70(2 \mathrm{H}$, br d, py- $H)$, $9.29\left(2 \mathrm{H}\right.$, br t, $\left.N H \mathrm{CH}_{2}\right)$; ESI-MS, $m / z(\%): 945.55[3+\mathrm{H}]^{+}, 968.54$ $[3+\mathrm{Na}]^{+}, 983.51[3+\mathrm{K}]^{+}$.

\section{Reaction of 3 with $\mathrm{Hg}\left(\mathrm{ClO}_{4}\right)_{2}$}

A mixture of $3(0.05 \mathrm{~g}, 0.53 \mathrm{mmol})$ and mercury(II) perchlorate $(0.21 \mathrm{~g}, 0.53 \mathrm{mmol})$ in ethanol $(25 \mathrm{ml})$ was stirred at r.t. for $2 \mathrm{~h}$. Upon completion of the reaction the volatiles were removed under pressure to give a crude solid which was then examined by NMR spectroscopy. $\delta_{\mathrm{H}}\left(500 \mathrm{MHz} ; \mathrm{CDCl}_{3} ; \mathrm{Me}_{4} \mathrm{Si}\right) 0.79(9 \mathrm{H}, \mathrm{s}, t-\mathrm{Bu}), 0.91$ $(9 \mathrm{H}, \mathrm{s}, t-\mathrm{Bu}), 1.23(9 \mathrm{H}, \mathrm{s}, t-\mathrm{Bu}), 1.28(9 \mathrm{H}, \mathrm{s}, t-\mathrm{Bu}), 2.53(1 \mathrm{H}, \mathrm{d}$, $\left.J=13.2 \mathrm{~Hz}, \mathrm{OCH}_{2} \mathrm{CO}\right), 2.83\left(1 \mathrm{H}, \mathrm{d}, J=13.0 \mathrm{~Hz}, \mathrm{OCH}_{2} \mathrm{CO}\right)$, $3.35\left(1 \mathrm{H}, \mathrm{d}, J=12.9 \mathrm{~Hz}, \mathrm{OCH}_{2} \mathrm{CO}\right), 3.43(1 \mathrm{H}, \mathrm{d}, J=14.6 \mathrm{~Hz}$, $\mathrm{ArCH} 2 \mathrm{Ar}), 3.46\left(1 \mathrm{H}, \mathrm{d}, J=14.6 \mathrm{~Hz}, \mathrm{ArCH} \mathrm{Ar}_{2}, 4.02(1 \mathrm{H}, \mathrm{d}, J=\right.$ $\left.13.9 \mathrm{~Hz}, \mathrm{ArCH} \mathrm{H}_{2} \mathrm{Ar}\right), 4.17\left(1 \mathrm{H}, \mathrm{d}, J=12.8 \mathrm{~Hz}, \mathrm{OCH}_{2} \mathrm{CO}\right), 4.36$ $\left(1 \mathrm{H}, \mathrm{d}, J=13.2 \mathrm{~Hz}, \mathrm{ArCH} \mathrm{Ar}_{2} \mathrm{Ar}, 4.38\left(1 \mathrm{H}, \mathrm{d}, \mathrm{NHCH}_{2}\right), 4.73(\mathrm{~d}\right.$, $J=8.4 \mathrm{~Hz}), 5.18\left(1 \mathrm{H}, \mathrm{dd}, \mathrm{NHCH}_{2}\right), 5.28(1 \mathrm{H}, \mathrm{d}, J=17.5 \mathrm{~Hz}$, $\left.\mathrm{ArCH} \mathrm{H}_{2} \mathrm{Ar}\right), 5.85\left(1 \mathrm{H}, \mathrm{d}, J=15.7 \mathrm{~Hz}, \mathrm{ArCH} \mathrm{H}_{2} \mathrm{Ar}\right), 6.08(1 \mathrm{H}, \mathrm{dd}$, $\left.\mathrm{NHCH}_{2}\right), 6.49(1 \mathrm{H}, \mathrm{s}, \mathrm{Ar}-H), 6.56(1 \mathrm{H}, \mathrm{s}, \mathrm{Ar}-H), 6.71(1 \mathrm{H}, \mathrm{s}, \mathrm{Ar}-$ $H), 6.73(1 \mathrm{H}, \mathrm{s}, \operatorname{Ar}-H), 6.84(1 \mathrm{H}, \mathrm{s}, \operatorname{Ar}-H), 7.00(1 \mathrm{H}, \mathrm{s}, \operatorname{Ar}-H)$, $7.03(1 \mathrm{H}, \mathrm{s}, \mathrm{Ar}-H), 7.08(1 \mathrm{H}, \mathrm{br} \mathrm{t}, \mathrm{py}-H), 7.12(1 \mathrm{H}, \mathrm{s}, \mathrm{Ar}-H), 7.24$ $(1 \mathrm{H}, \mathrm{s}, \mathrm{Ar}-H), 7.24(1 \mathrm{H}$, s, calix- $O H), 7.36(1 \mathrm{H}, \mathrm{s}$, calix- $O H), 7.38$ $(1 \mathrm{H}, \mathrm{t}, \mathrm{py}-H), 7.49(1 \mathrm{H}, \mathrm{d}, \mathrm{py}-H), 7.95(1 \mathrm{H}, \mathrm{d}, \mathrm{py}-H), 8.10(1 \mathrm{H}$, t, py- $H), 9.04(1 \mathrm{H}, \mathrm{t}, \mathrm{py}-H), 9.35\left(1 \mathrm{H}, \mathrm{t}, N H \mathrm{CH}_{2}\right), 9.61(1 \mathrm{H}, \mathrm{d}$, py- $H), 10.12(1 \mathrm{H}, \mathrm{d}$, py- $H), 10.35\left(1 \mathrm{H}, \mathrm{t}, N H \mathrm{CH}_{2}\right)$; ESI-MS, $m / z$ (\%): $945.54[3+\mathrm{H}]^{+}, 968.53[3+\mathrm{Na}]^{+}$.

A mixture of $3(0.05 \mathrm{~g}, 0.53 \mathrm{mmol})$ and mercury(II) perchlorate $(0.21 \mathrm{~g}, 1.06 \mathrm{mmol})$ in ethanol $(25 \mathrm{ml})$ was heated to reflux while stirring for $2 \mathrm{~h}$. After cooling, the volatiles were removed under pressure to give a crude solid which was then examined by NMR spectroscopy. $\delta_{\mathrm{H}}\left(300 \mathrm{MHz} ; \mathrm{CDCl}_{3} ; \mathrm{Me}_{4} \mathrm{Si}\right) 0.99(9 \mathrm{H}, \mathrm{s}, t-\mathrm{Bu}), 1.02$ $(9 \mathrm{H}, \mathrm{s}, t-\mathrm{Bu}), 1.16\left(6 \mathrm{H}, \mathrm{t}, J=7.1 \mathrm{~Hz}, \mathrm{OCH}_{2} \mathrm{CH}_{3}\right), 1.28(18 \mathrm{H}, \mathrm{s}, t-$ $\mathrm{Bu}), 3.34\left(2 \mathrm{H}, \mathrm{d}, J=13.1 \mathrm{~Hz}, \mathrm{ArCH} \mathrm{H}_{2} \mathrm{Ar}\right), 3.40(2 \mathrm{H}, \mathrm{d}, J=13.1 \mathrm{~Hz}$, $\mathrm{ArCH} 2 \mathrm{Ar}), 3.99\left(4 \mathrm{H}, \mathrm{q}, J=7.1 \mathrm{~Hz}, \mathrm{OCH}_{2} \mathrm{CH}_{3}\right), 4.23(2 \mathrm{H}, \mathrm{d}, J=$ $\left.13.1 \mathrm{~Hz}, \mathrm{ArCH}_{2} \mathrm{Ar}\right), 4.25\left(2 \mathrm{H}, \mathrm{d}, J=13.1 \mathrm{~Hz}, \mathrm{ArCH} \mathrm{H}_{2} \mathrm{Ar}\right), 4.62$ $\left(4 \mathrm{H}, \mathrm{s}, \mathrm{OCH}_{2} \mathrm{CO}\right), 4.92\left(4 \mathrm{H}\right.$, br d, $\left.\mathrm{NHCH}_{2}\right), 6.86(2 \mathrm{H}, \mathrm{s}, \mathrm{Ar}-\mathrm{H})$, $6.90(2 \mathrm{H}, \mathrm{s}, \mathrm{Ar}-\mathrm{H}), 7.07(6 \mathrm{H}, \mathrm{m}, \mathrm{Ar}-\mathrm{H} \&$ calix- $\mathrm{OH}), 7.60(3 \mathrm{H}, \mathrm{m}$, py- $H), 8.52(1 \mathrm{H}, \mathrm{d}$, py- $H), 9.24\left(1 \mathrm{H}\right.$, br t,$\left.N H \mathrm{CH}_{2}\right)$.

\section{NMR Reactions}

A mixture of $3(0.01 \mathrm{~g}, 0.01 \mathrm{mmol})$ and either a mercury salt (i.e. mercury(II) perchlorate, mercury(II) chloride, mercury(II) thiocyanate), a zinc salt (zinc(II) perchlorate) or a silver salt (silver(I) perchlorate) $(0.01 \mathrm{mmol})$ was dissolved in a deuterated solvent (i.e. $\mathrm{CDCl}_{3}, d_{6}-\mathrm{DMSO}, \mathrm{CD}_{3} \mathrm{CN}$ or $\mathrm{CD}_{2} \mathrm{Cl}_{2}$ ). After shaking, the mixture was placed into an NMR tube and analysed using NMR spectroscopy. The resulting NMR data is presented in the supplementary information. $\dagger$

\section{NMR Titrations}

Titrations are only described for $\mathrm{d}_{6}$-DMSO solutions, but titrations in other solvents were carried out in a similar manner. Standard solutions of $\mathbf{3}$ and the mercury(II) salts (mercury(II) perchlorate, mercury(II) chloride and mercury(II) thiocyanate) were prepared in $\mathrm{d}_{6}$-DMSO. These solutions were then diluted to a concentration of $1 \times 10^{-4} \mathrm{M}$ respectively. $0.5 \mathrm{ml}$ of the calixarene were then placed in an NMR tube and examined using ${ }^{1} \mathrm{H}$ NMR spectroscopy. $50 \mu \mathrm{m}(0.2 \mathrm{Eq})$ of the appropriate mercury(II) salt solution was then added to the NMR tube and the resulting complex was examined as before. These titrations continued until the complex formation had been examined with $0.2,0.4,0.6,0.8,1.0,2.0,4.0,6.0,8.0$ and 10.0 equivalents of $\mathrm{Hg}$ salt present. The resulting NMR data is presented in the supplementary information. $\dagger$

\section{Conclusions}

The mercury ion complexation reactions were carried out between the calix[4]arene derivative and various mercury(II) salts. ${ }^{1} \mathrm{H}$ NMR studies showed that the role of solvent, the anion chosen and the initial reaction conditions were critical and that the formation of a "simple" mercury(II) complex was non-trivial. The mercury ion can cause either (i) the formation of an ion-pair system, which have a characteristic downfield shift of all signals in the ${ }^{1} \mathrm{H}$ NMR spectrum, (ii) a cleavage reaction to occur resulting in the reformation of the calix[4]arene diester compound $\mathbf{2}$, but only when the reaction is heated and (iii) "simple" mercury binding to the pyridine rings when the binding studies are carried out using NMR titration techniques. The electrochemistry data show a large shift in ligand oxidation potential in the presence of $\mathrm{Hg}\left(\mathrm{ClO}_{4}\right)_{2}$ which is characteristic of complexation. The magnitude of the 
shift is $c a .260 \mathrm{mV}$ and, thus, we can infer that the $\mathrm{Hg}^{2+}$ species is strongly complexed. This is also reflected in the diminished $\mathrm{Hg}^{0}-\mathrm{Hg}^{2+}$ stripping peak observed after the first cycle. $\mathrm{AgClO}_{4}$ also causes a shift, albeit smaller, in the ligand oxidation potential but the $\mathrm{Ag}^{0}-\mathrm{Ag}^{+}$transition stripping peak remains constant over the range of voltammetric cycles. This indicates that while $\mathrm{Ag}^{+}$ may bind to the ligand, the binding is not tight and may be a binding/non-binding equilibrium process. However, activation energy or power is being applied in both the electrochemical reactions and also in the case where the reaction is heated. In all of these cases, simple metal binding is not observed but more complicated reaction pathways occur. Further investigations into this system are under way.

\section{Acknowledgements}

We thank John F. Gallagher, John C. Stephens and Carmel B. Breslin for useful discussions, Orla Fenelon for mass spectrometry data and Andrew D. Bond for confirming the X-ray crystal structure of 3. DFD acknowledges financial assistance from the Postgraduate Research and Development Skills Programme (Technological Sector Research, Strand I) and the Institute of Technology Tallaght Dublin PhD continuation fund.

\section{Notes and references}

1 C. J. Elsevier, J. Reedijk, P. H. Walton and M. D. Ward, J. Chem. Soc., Dalton Trans., 2003, 1869-1880.

2 D. L. Caulder and K. N. Raymond, Acc. Chem. Res., 1999, 32, 975-982.

3 D. W. Bruce and D. O'Hare, Inorganic Materials, Wiley, Chicester, 1996.

4 F. Vögtle, Supramolecular Chemistry, Wiley, Chicester 1991.

5 A. Ikeda and S. Shinkai, Chem. Rev., 1997, 97, 1713-1734.

6 C. Wieser, C. B. Dieleman and D. Matt, Coord. Chem. Rev., 1997, 165, 93-161.

7 C. D. Gutsche, Calixarenes Revisited: Monographs in Supramolecular Chemistry, Royal Society of Chemistry, London, 1998.

8 L. Mandolini and R. Ungaro, Calixarenes in Action, Imperial College, London, 2000.

9 Z. Asfari, V. Böhmer, J. Harrowfield and J. Vicens, Calixarenes 2001, Kluwer Academic, Dordrecht, 2001.

10 P. D. Beer and E. J. Hayes, Coord. Chem. Rev., 2003, 240, 167-189.

11 C. Redshaw, Coord. Chem. Rev., 2003, 244, 45-70.

12 W. Śliwa, J. Inclusion Phenom. Macrocyclic Chem., 2005, 52, $13-37$.

$13 \mathrm{~J}$. Vicens and J. Harrowfield, Calixarenes in the Nanoworld, Springer, Netherlands, 2007.

14 B. S. Creaven, D. F. Donlon and J. McGinley, Coord. Chem. Rev., 2009, 253, 893-962.
15 For recent papers on ion-pair binding with calixarene receptors, see, for example: (a) L. Pescatori, A. Arduini, A. Pochini, A. Secchi, C. Massera and F. Ugozzoli, Org. Biomol. Chem., 2009, 7, 3698-3708; (b) M. Hamon, M. Ménand, S. Le Gac, M. Luhmer, V. Dalla and I. Jabin, J. Org. Chem., 2008, 73, 7067-7071; (c) M. D. Lankshear, I. M. Dudley, K.-M. Chan, A. R. Cowley, S. M. Santos, V. Felix and P. D. Beer, Chem.-Eur. J., 2008, 14, 2248-2263; (d) S. Le Gac and I. Jabin, Chem.-Eur. J., 2008, 14, 548-557; (e) M. D. Lankshear, N. H. Evans, S. R. Bayly and P. D. Beer, Chem.-Eur. J., 2007, 13, 3861-3870; $(f)$ T. Nabeshima, T. Saiki, J. Iwabuchi and S. Akine, J. Am. Chem. Soc., 2005, 127, 5507-5511.

16 S. Pappalardo, L. Giunta, M. Foti, G. Ferguson, J. F. Gallagher and B. Kaitner, J. Org. Chem., 1992, 57, 2611-2624.

17 G. Ferguson, J. F. Gallagher and S. Pappalardo, J. Inclusion Phenom. Mol. Recognit. Chem., 1992, 14, 349-356.

18 A. D. Bond, B. S. Creaven, D. F. Donlon, T. L. Gernon, J. McGinley and H. Toftlund, Eur. J. Inorg. Chem., 2007, 749-756.

19 B. S. Creaven, T. L. Gernon, J. McGinley, A.-M. Moore and H. Toftlund, Tetrahedron, 2006, 62, 9066-9071.

20 B. S. Creaven, T. L. Gernon, T. McCormac, J. McGinley, A.-M. Moore and $\mathrm{H}$ Toftlund, Inorg. Chim. Acta, 2005, 358, 2661-2670.

21 B. S. Creaven, M. Deasy, J. F. Gallagher, J. McGinley and B. A. Murray, Tetrahedron, 2001, 57, 8883-8887.

22 B. S. Creaven, M. F. Mahon, J. McGinley and A.-M. Moore, Inorg. Chem. Commun., 2006, 9, 231-234.

23 J. McGinley, V. McKee, H. Toftlund and J. M. D. Walsh, Dalton Trans., 2009, 8406-8412.

24 R. Joseph, B. Ramanujam, A. Acharya, A. Khutia and C. P. Rao, J. Org. Chem., 2008, 73, 5745-5758.

25 E. M. Collins, M. A. McKervey and S. J. Harris, J. Chem. Soc., Perkin Trans. 1, 1989, 372-374.

26 B. Balázs, G. Tóth, G. Horváth, A. Grün, V. Csokai, L. Töke and I. Bitter, Eur. J. Org. Chem., 2001, 61-71.

27 A. F. D. De Namor, S. Chahine, E. E. Castellano and O. E. Piro, J. Phys. Chem. A, 2005, 109, 6743-6751.

28 A. F. D. De Namor, A. Aguilar-Cornejo, R. Soualhi, M. Shehab, K. B. Nolan, N. Ouazzani and L. Mandi, J. Phys. Chem. B, 2005, 109, 14735-14741.

29 A. F. D. De Namor, S. Chahine, D. Kowalska, E. E. Castellano and O. E. Piro, J. Am. Chem. Soc., 2002, 124, 12824-12836.

30 P. D. Beer, M. G. B. Drew and K. Gradwell, J. Chem. Soc., Perkin Trans. 2, 2000, 511-519.

31 A. J. Bard and L. R. Faulkner, Electrochemical Methods: Fundamentals and Applications, 2nd ed., Wiley, New York, 2001.

32 (a) A. Pailleret, G. Herzog and D. W. M. Arrigan, Electrochem. Commun., 2003, 5, 68-72; (b) R. Vataj, A. Louati, C. Jeunesse and D. Matt, Electrochem. Commun., 2000, 2, 769-775.

33 (a) R. S. Nicholson and I. Shain, Anal. Chem., 1964, 36, 706-723; (b) R. S. Nicholson and I. Shain, Anal. Chem., 1965, 37, 178-190; (c) R. S. Nicholson and I. Shain, Anal. Chem., 1965, 37, 190-195.

34 R. C. Nelson and R. N. Adams, J. Electroanal. Chem., 1968, 16, 439442 .

35 L. N. Balyatinskaya, Russ. Chem. Rev., 1979, 48, 418-429.

36 S. B. Khoo and S. X. Guo, Electroanalysis, 2002, 14, 813822 . 